\title{
アジアにおける土地利用・被覆研究ガイドライン
}

佐 藤 洋 平*

\author{
1. 序論
}

地球環境問題は 1972 年のストックホルム会議（国連人間環境会議）から 1992 年の地球サミット (UNCED) を経て, 同問題の学術的研究の重要性が益々増してきている。そうした中で, ICSU (国際学 術連合会議) や ISSC（国際社会科学協議会）はそれぞれIGBP（地球圈一生物圈国際共同研究計画）及 び HDP（地球環境変化の人間次元的の研究計画）と地球環境について国際的な研究プログラムを企画 し，現在それが実行に移されつつある。そうした中で，IGBP および HDP は共通で，LUCC-CPPC(土 地利用・被覆変化一コアプロジェクト計画委員会）を設け，新しい研究コアプロジェクト LUCC/IGBPHDP 1995 年より発足させる状況となった。日本としても，この国際共同研究プログラムに相応の貢 献が必要となってきた。この研究プロジェクトに対して, 第 15 期日本学術会議では, IGBP 専門委員会 に土地利用小委員会を作ってその研究体制固めを行ってきた。そして第 16 期になってからは地球環境研 究連絡委員会の中に IGBP 専門委員会及び HDP 専門委員会が設けられ，共同で土地利用小委員会を構 成し推進している。

一方, 国立環境研究所は, Eco-Asia 計画でアジア地域の地球環境保全への貢献プログラムを作成して いるが，その一環としてLUCCについても協力する体制を作ろうとしてきている。そこで，国立環境研 究所の作成する LUCC 研究計画も，できる限り国際的な LUCC 研究計画の趣旨に合わせるよう企画さ れることが望まれている。LUCC-CPPC は 1994 年 6 月の守山会議で第 3 ドラフトの検討を行い, 現在最 終案を作成している。国立環境研究所はこの LUCC-CPPC 会議後にLUCC Japan Workshop を京都で 開いて日本側 LUCC 研究計画と国際的な LUCC 研究計画との意見調整を行ってきた。この研究計画は こうした状況を踏まえ, 日本としてアジア地域において LUCC 研究をすすめるためのガイドラインとし て作成してものであり，これを発表する。

\section{2. 研究の目的と研究構成}

\section{1 研究の目的}

この研究は, アジア地域における地球環境問題の基礎となる土地利用・被覆に関する次の諸課題を解 決することを目的として実施する。

(1) 土地利用・被覆変化に関する実態を把握し，同データベースを構築する

(2) 土地利用・被覆変化の要因及びそれが地球環境変化に及ぼす要因を明らかにする

(3) 土地利用・被覆変化の予測モデルを構築する

(4) 地球環境問題, とくに土地利用・被覆変化を解決のための政策モデル構築し, 地球環境問題への 土地利用・被覆改善政策からの提言を行う

* 筑波大学 


\section{2 研究対象地域}

この研究は, アジア関係諸国の共同研究によって, アジア地域のうち, IGBP-START の TEA, SARCS, SAS 地域について実施する。実施に当たっては, IGBP-START 研究の基礎的フレームを踏ま えて, 当該地域をTEA, SARCS, SAS に分けて実施する。ただし, 研究の出発に当たって, 日本として は，まずTEA, SARCS を中心に開始する。

\section{3 研究構成}

LUCC/IGBP・HDP 研究計画にできる限り協調していく仕組みとする。しかし, 同研究計画は現在作 成中で第 3 Draft では 3 つの Focusに分かれている。しかし，わが国の場合には 4 つの Focus に分けて 実施する。各Focus の主要な内容は下記のとおりである。

[Focus 1: デー夕の図化/地域分類]

この Focus は LUCC/IGB・HDP の Focus 2 (Land-Cover Change Patterns) にデータベース構築 を含めたもので, 研究をスムーズに展開する上で $5 つ$ Taskに分けて実施する。Task 1 で, 各種デー 夕の単位を検討し, 地域の七エラルキー体系を分析するとともに, データベースの基礎となるデー夕単 位を明確にする。その上で, 生物・物理的デー夕と社会・経済的デー夕を収集し，それぞれのデータベー スを作成する。こうしたデータベースを活用しつつ，各データの図的表示及び空間タイプの分析を行つ て地域分類を行う。この地域分類を参考にしつつ，Focus 2 のケーススタディ地域を選定する。

[Focus 2: ケーススタディ]

この Focus は IGBP-LUCC の Focus 1 (Land-Use Change Processes (Situations)) に相当するケー ススタディである。IGBP-LUCC の Focus 1 は社会・経済的ケーススタディに傾いているが，我々の場 合は生物・物理的ケーススタディも含まれた総合的ケーススタディである。これは $(\mathrm{x}+1)$ つの Taskに 分けられ，Task 1〜Task x まではケーススタディで，地域別の Task $(\mathrm{x}+1)$ はこれらケーススタディ の比較研究である。

ケーススタディでは, 人口増大による耕地面積の拡大, 都市化に伴う農地減少, 農地の地力低下等の いくつかの地球環境保全上のテーマを設定し，それについての詳細な因果関係を分析する。この分析に 当たっては地域内をいくつかの地域類型別地域に分け, 各地域類型別に各テーマを分析する。こうした 地域類型別分析に基づいて各地域類型別モデルを作成し, 総合的地域モデル構築 (Focus 3) の基本的情 報を提供する。

[Focus 3: モデリング]

この Focus 3 は, IGBP-LUCC の Focus 3 にほぼ相当する。この Focus では, Task 1〜3でアジア 地域の TEA, SARCS, SAS 別のモデルを構築し, グローバルなモデリングの基礎を作る。その上で, 他 地域の情報を得てグローバルなモデル研究を行う。モデリングについては, 地域類型別モデルの組み合 わせモデルを軸としつつも,ここでは地域類型間の相互関係に留意した総合的モデル構築に心がける。モ デルによる土地利用・被覆変化の予測を行うとともに，その変化要因を究明し，Focus 4 の政策提言を 考究していく上での基礎とする。

[Focus $4:$ 統合と政策方針]

この Focus 4 は, IGBP-LUCC では特に Focus として組まれていないが，上記 Focus 1-3 の統合から 政策方針策定に責任をもつ Focus である。この Focus は，まず Task 1 で Focus 1-3 を統合し，土地利 用・被覆変化研究を総括し，その予測をする。一方，Task 2 は，その地域分類によって得られた重点対 策地域ごとに解決方策を軸にした地球環境保全のための政策モデルを追求する。そして，この Task 2 に 


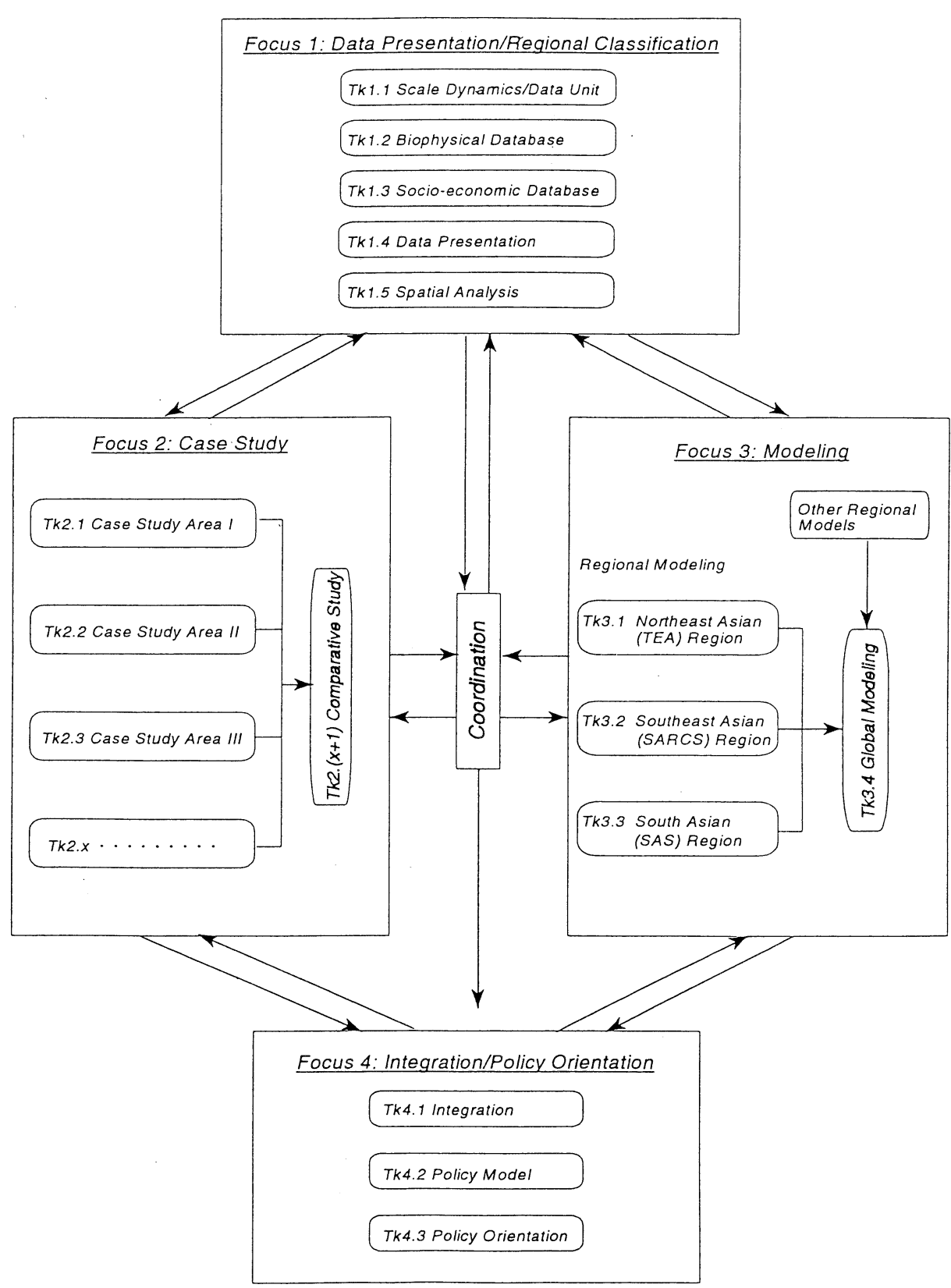

図 1 研究の構 成

よって得られた成果を基にして，土地利用・被覆政策からの具体的地球環境保全に対する提言をする。

\section{3. 理論的アプローチ}

次に土地利用・被覆変化研究と地球環境保全との関連性を明らかにしていくための基礎的共通認識を 作るための考え方について述べる。 


\section{1 地球環境保全}

本研究は, 地球環境保全のための土地利用・被覆研究であるが，その目的となる地球環境保全も漠然 と捉えるのではなく，その保全目的を明確にして，その研究方針を固める必要がある。そこで，研究に 当たっては，目的意識を明確にする必要がある。

例示的に目的意識を分類してみると，次のようになる。

(1) フロンガス, $\mathrm{CO}_{2}, \mathrm{NO}_{\mathrm{x}}$ 等の空気の浄化，気象環境等の改善を行うこと。

これによって, 酸性雨, 温暖化, 温暖化に伴う陸地の変化, オゾンホールの拡大等を防止する。土地 利用・被覆研究としては，土地利用・被覆とこれらのガスの発生メカニズムを究明する。

(2) 食糧を安全に確保すること

人口増, 農地の劣化等による食糧不足を解消することが必要である。このための土地利用・被覆研究 としては, 人口増のメカニズム, 同コントロール, 農地劣化のメカニズムとその改善策等にからむメカ ニズムの解明が不可欠である。

(3) 食糧以外の生活・産業資材の安全供給

木材, エネルギー等の生活・産業資材が安定的に供給されるようにする必要がある。土地利用・被覆 研究としては, これらの問題に対し, 各地域類型別に主要生活・産業資材の供給, 同不足のメカニズム を究明し，その安全策を講ずる必要がある。

(4) 生活環境の安定化

生態系の保全は, 生態系を単に趣味的保全することではない。生態系という人為的変更不可能な自然 界の生物連鎖系をできる限り自然の状況におきそれによって生活環境の突発的異変を解消することを指 している。また水質保全，土地利用秩序など人間の生存に直接かかわる環境の安定化が必要である。

いずれにしても，地球環境保全の具体的目的を明確にし，各ケーススタディの課題をはっきりさせる 基礎とする必要がある。

\section{2 地域構造}

人間活動と地球環境との関係を考える上で，その各種要因間のマクロな関連性について，研究者が共 通認識を持つことが必要である。ところが，そうした共通認識そのものは研究過程から作り出されるも のであるから，研究計画の段階で触れることはそもそも無理がある。

しかし, 専門を異にする研究者がかかわる以上全体的研究目的の何かを明らかにし，何を分担するか についても，大まかでもある程度の共通的認識が不可欠といえる。ここでは，こうした全体認識に役立 てるための地域構造認識についての一つの考え方を述べる。ここでいう地域構造とは，人間活動を中心 にして地表面上に原始的地球環境を修正して出来上がった自然と人間の総合的関係の総体を指してい る。

すなわち人間活動は生産系活動，生活系活動及び公共系活動に分けて捉える。その上で，これら人間 活動の相互活動を支える要素として社会, 経済, インフラストラクチャー(物象), 空間及び環境(狭義) が存在すると理解する。

そこで, 土地利用, 広義に理解すれば空間利用は, 人間活動が社会, 経済, インフラストラクチャー 及び環境との関係で生みだした土地に対する人間活動の反映である。そして，土地被覆は土地利用の結 果が地表面上に反映されて出来上がったものという理解ができる。

換言すると, 環境から資源を形成する人間活動がいわば土地利用である。しかし，このようなアプロー チをとると，地域社会全体のモデリングを考えることが土地利用の分析となって本研究の枠組みをはる 


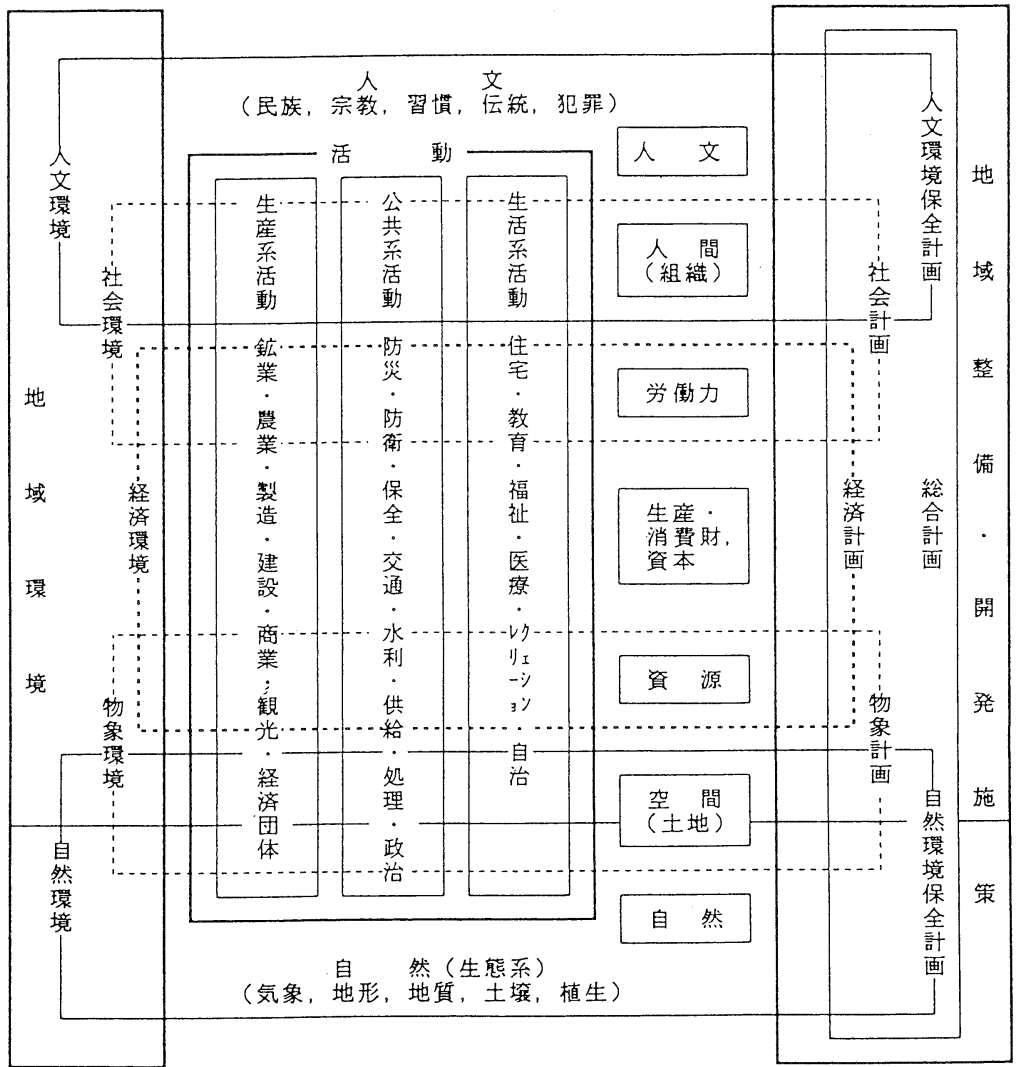

図 2 地域構造概念図

かにこえることとなってしまう。そこで，本研究ではむしろ，土地被覆に色どられた人間活動を軸に地 域を見直し，逆に土地被覆を軸にして土地利用を見るようにしてみる。

すなわち, 都市地域の都市的活動, 農村地域の農業活動と林業活動, それから乾燥地や湿地の人間活 動とくくって表現しているが，いずれの活動においても先に述べた生産系，生活系，公共系の各人間活 動が組み合わさったものであることには変わらない。そして，そうした各活動は環境から資源を生み出 す活動であって，それが結果として土地利用・被覆に表されている。

\section{3 生活圏と地域階層}

人間活動は，一般的に各人間ごとに一定の領域内で限られた活動を展開している。しかし，その領域 も日常的な活動と月に 1 回くらいとか 3 ケ月に 1 回くらい,さらに 1 年に 1 回くらいの活動によって広 がってくる。そうした人間活動に伴って生じる地域を影響圈とか生活圈といっており，それが人間活動 の頻度と重ね合わせて地域規模によってヒエラルキー状に連鎖していると理解している。これを通常地 域ヒエラルキーといっている。各地域にはこうした地域ヒエラルキーが歴史的に形成されてきている。そ して，どこの国でもこれが行政区域等に反映されてきている。研究に当たっては，各国の協力を得て各 国等の地域ヒエラルキー体系と地方行政区域との関係を検討する必要がある。その上で，社会・経済的 データの単位を決定する。 


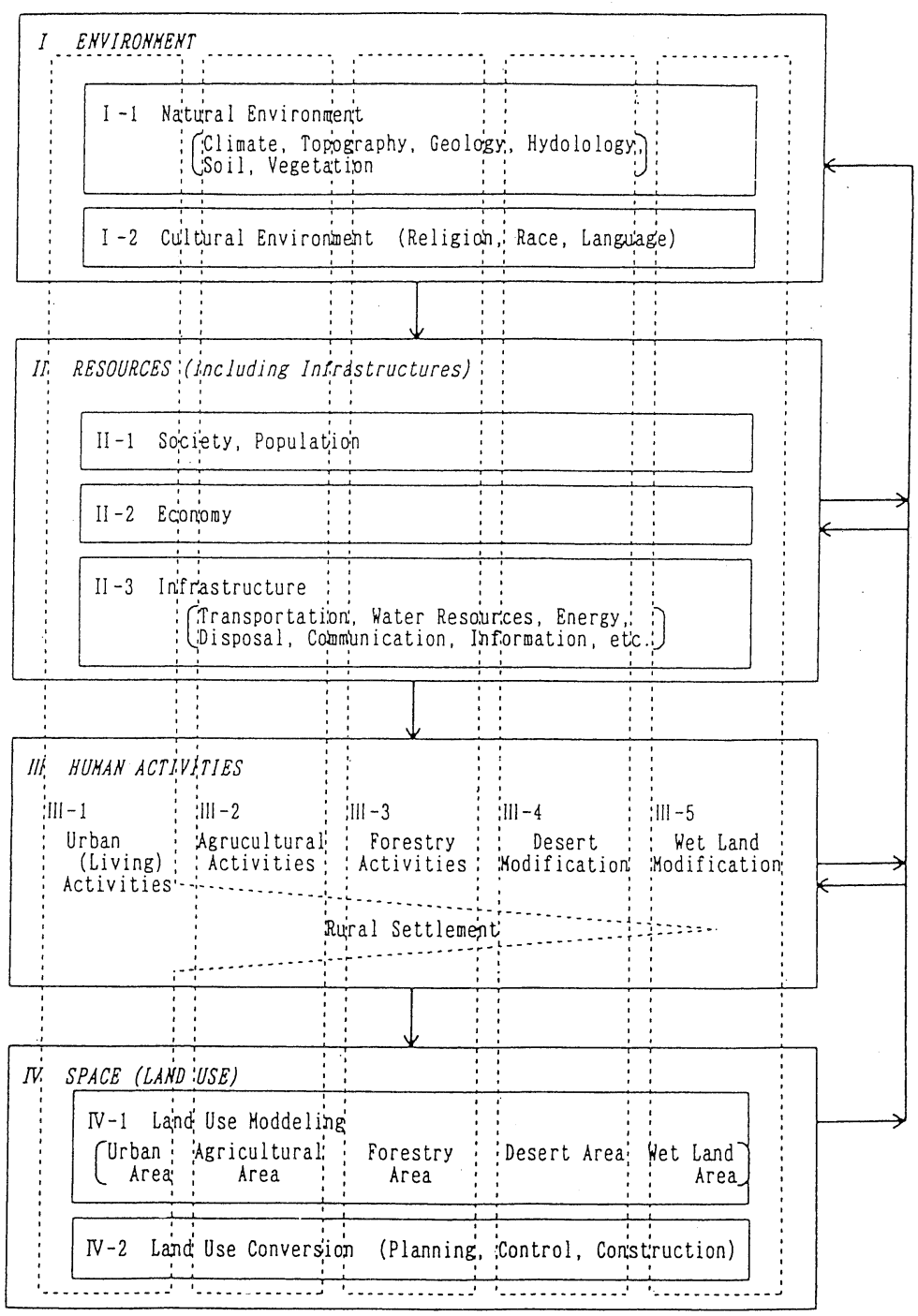

図 3 Regional Structure (Environment, Resources, Human Activities, and Land Use)

\section{4 土地利用・被覆}

一口に土地利用・被覆といっても，その概念を明らかにしておく必要がある。常識的にいう土地被覆 種（農用地，集落用地，工業用地等といった区分）は，少なくとも $1 / 10,000$ の地図でなければ認識でき ない。ところがこれより小縮尺の地図で土地被覆種が語られるが，例えば，水田地域といっても水田ば かりでなく，そこに道路，集落，河川といった別の土地被覆が含まれている。

したがって, 本研究の実施に当たっては, 土地被覆種のカテゴリーを地域規模別に検討し, 地図スケー ル上どのように土地被覆を認識するかを明確にしなくてはならない。一方，土地利用についても，その スケールに応じた把握方法を明確にする必要があり，特に，土地利用主体をどう認識するかが重要なポ イントでもある。 


\section{5 土地利用・被覆変化モデル}

本研究に扔いて，大切なことは，Focus 2 のケーススタディチームと Focus 3 のモデルチームとの間 で, 土地利用・被覆変化モデルの全体的構造について, できる限り共通的認識を持つことである。当面, 本研究で指向する土地利用・被覆変化モデルの基本的構造は, 各地域類型別土地利用・被覆変化の推定 方法を組み合わせて推定モデルとする方向で考えている。もちろん，ケーススタディによっては，そう した単純な積み重ねでは推定しかねる問題もあろう。しかし，まず第一次近似は上記のようなできる限 り単純なモデルで考える。いずれにしても，モデルの基本構造を十分に検討しておく必要がある。

\section{6 地球環境保全政策}

地球環境保全の研究は華やかであるが, 具体的地球環境保全の具体策についての研究は, ぞちらかと いえば漠然としており，個別的・分散的である。地球環境は面的広がりを持つものであるので，ある地 域単位に統一的・総合的に地域環境保全策を実施していく必要がある。そのためには，地域単位に戦略 的地球環境保全策のあり方を究明していかなくてはならない。そうした観点から, 土地利用・被覆研究 の締めくくりとして，地域べースで，しかも総合的・統一的な地球環境保全への方策を提言していく必 要があると考える。

\section{Focus 2:}

\section{1 ケーススタディ}

ケーススタディは各研究者ごとに独自の研究アプローチに従いデータの収集を前提にそれぞれの調 査・研究の枠組みに沿って実施する。ケーススタディ地域全体としては, まず地域内をいくつかの副地 域に分類する。次にこれらの副地域を次のいずれかの類型に分類し, これらの地域の地域類型別の土地 利用・被覆変化特性を把握する。
a. 都市・工業地域
b. 水田地域
c. 畑作地域
d. 牧草地域
e. 林業地域
f. 乾燥地域
g. 沼地地域

\section{2 比較研究}

上記研究で得られた各地域類型別土地利用・被覆変化の特性を分析するとともに，そうした地域類型 別土地利用被覆変化を比較検討する。そしてその成果を土地利用・被覆変化モデル構築の基本的情報と する。

\section{Focus 3：地域・地球モデル}

\section{1 地域モデルの主なアプローチ}

地域分類によるケーススタディから，代表的地域類型別の土地利用・被覆変化セデルが，単純な型で はあるが求められてくる。したがって，こうしたモデルを基礎として，地域モデルを構築していく。 この地域モデルの構築に当たっては, 再び地域分類を検討し, 対象とする地域モデル内の地域分類を 
定めた上で,それぞれの地域類型別地域に地域類型別モデルを適用して総合的地域モデルを構築する。も ちろん，これは第一近似モデルであるので，この近似モデルを基にして，各国ではさらに詳細なモデル が検討されることが望まれる。

\section{2 地域モデルとアジアモデル}

地域モデルはすでに述べたように TEA, SARCS，及びSAS 地域別に構築する。そうした地域モデル の成果に基づいてアジアモデルを作成する。

\section{3 地球モデルへの貢献}

アジアモデル構築と同様の方法により，他地域の LUCC 研究の成果を基にして地球モデルを構築し， LUCC 研究全体としての成果の一端に寄与する。

\section{Focus 4 : 統合と政策方針}

\section{1 統合の方法}

ここでは, Focus 2 の成果と Focus 3 で得られたモデルを比較し, モデルとしての有効性等を検討す る。そして，地球環境保全上，特に留意すべき重点対策地域を選定する。

\section{2 政策モデルの開発}

6.1 で得られた重点対策地域について, 土地利用・被覆政策を軸にして, 各種の政策変数が組み込まれ た地球環境保全モデルを作成する。このモデルは，どの時点でどの政策を導入し，かつ「どのようにし て, 重点政策地域を持続的発展可能な自立的地域社会として行くか」という課題に対応するモデルであ る。したがって, このモデルの構築によって, 地球環境保全政策作成上の基礎的知見が得られる。

\section{3 地球環境保全政策指針}

ここでは, Focus 3 のモデル, Focus 2 のケーススタディをベースにして，総括的政策方針を打ち出 すとともに，政策モデルを通じて，拠点的に地球環境保全政策を展開する指針も明らかにする予定であ る。 